\title{
Depression and Hopelessness in Secondary and Higher Education Students
}

\author{
Ali Haydar ŞAR \\ Sakarya University, Turkey
}

\section{Introduction}

Secondary and higher education students draw attention as periods which should be closely watched in terms of development. This period is important for young people entering adulthood and developing an identity. During this period, students encounter many of the psychological problems, such as Depression and Hopelessness which are some of the most serious psychological problems which include risk of suicide and which negatively affect mental, emotional, social and physical functions. Depression is a syndrome ${ }^{1}$ which includes symptoms such as mental collapse, deep sadness situation, slowing in speech and movements and calmness and slowing down in physiological functions with emotions and feelings of insignificance, indignity, powerlessness, reluctance and moodiness and a really serious disorder ${ }^{2}$ which may take the patient to suicide slowly unless it is treated ${ }^{2}$.

There are some problems which may occur with depression. Among these problems, sad facial expression, calmness, feeling of inadequacy, getting tired quickly, not being interested in anything, hopelessness ${ }^{3}$, slowing in mental functions, having difficulty in doing daily routines, often using words ${ }^{4}$ such as moodiness, pessimism, unhappiness, boredom, hopelessness generally, low selfrespect $^{5}$, problems regarding physical health ${ }^{6}$, increasing risk of drug addiction ${ }^{7}$, ruined parent relationship ${ }^{8}$, unsatisfying and ruined interaction in interpersonal relations, significant decrease in academic performance ${ }^{10}$ and increase in the risk of quitting school $^{11}$, negative mood and suicide risk $^{12}$, sleep disorders ${ }^{13}$, obesity problem $^{14}$ are commonly seen.

According to the studies, the university students coming to Psychological Consulting complain about depressive symptoms ${ }^{15}$, and there are depressive symptoms in serious levels among the adolescents of 12,55\%, adolescents 
experience insignificance, sadness, emptiness, temper and somatic disorders with problems of falling behind in class and being insulted in school ${ }^{16}$, girls are more inclined to depression and that causes them to fail in their courses ${ }^{17}$.

In depression, the individual not only looks at the events in the past or now pessimistically but also feels that this situation will never change and continue in that way when he/she looks at the future. In this case, he/she feels that there is no ray of hope for himself/herself and lives hopelessness feeling.

Hopelessness is pessimism in view of life and future, decreasing of or elimination of optimism $^{18 ; 19}$, a negative view towards future that anything that can happen in the future will not be better than now ${ }^{20 ;}$, and a belief that the goal of the future will not be achieved ${ }^{22}$. Individual who is in hopelessness thinks that the present difficulties and problems suffered will continue in a similar way and he/she will encounter with blockings, disappointments and deprivation when he/she looks at the future ${ }^{23}$. Hopelessness starts to develop when individuals start to think that they could no longer reach their aims and this pessimistic view of life becomes an important component of depression ${ }^{24}$.

When the literature on hopelessness is examined, it is observed that thought of suicide is quite related with hopelessness ${ }^{25}$; male university students who think that they will not be able to graduate once they graduate have higher hopelessness than female university students ${ }^{26}$; the hopelessness levels of the students who chose the department they study reluctantly and who perceive themselves as inadequate are higher ${ }^{27}$; hopelessness of preservice teachers who have a low future expectancy is higher ${ }^{28}$; students whose relation with their friends is low and whose families have low financial possibilities and who state their success status as bad have higher hopelessness levels ${ }^{29}$.

When the research results are examined, depression and hopelessness can be said to be problems which emotionally threat secondary and higher education students.

The aim of this study is to examine Depression and Hopelessness levels in students studying in secondary and higher education according to some variables. To this end, answers were sought for the following questions.

1-Do depression and hopelessness thoughts differ according to education level?

2-Do depression and hopelessness thoughts differ according to gender?

3- Do regular or vocational education programs the students studying in secondary education make the depression and hopelessness levels differ? 
4-Do different education programs in which the students in higher education study affect their depression and hopelessness thoughts?

\section{Method}

\section{Scope of the Research}

The universe of the study is constituted by the students studying in all faculties and collages of Aksaray University and high school students in the center affiliated to Aksaray Directorate of National Education.

The sample was constituted by 1050 students in total, 500 from university and 550 from high schools, who were selected by cluster sampling and then random sampling. 600 of the students included in the sampling were male and 450 were female.

\section{Instrument}

\section{1-Beck Depression Scale (BD)}

The aim of this scale which was developed by Beck et al. in 1978 is not to diagnose, but to determine the degree of symptoms objectively. The inventory whose adaptation studies were carried out by Hisli ${ }^{30}$ has a reliability of .74 and validity of .74. The inventory includes 21 questions and each question has four choices. The individual can get 63 points from the inventory and the level of the obtained point proves that depression is also high.

\section{2-Beck Hopelessness Scale}

It is a scale which was developed by Beck et al. and which aims to determine the pessimism level of the individual towards future. Beck Hopelessness Scale which includes 20 items consists of expressions which state feelings and thought toward future. The points which can be obtained from the scale vary between 0 and 20 . The level of the obtained score indicates that the hopelessness of the individual is high. Beck and Steer ${ }^{31}$ classified the subjects into four groups according to their answers and they stated that 0 - 3 indicate no hopelessness, 4 - 8 indicate slight hopelessness, 9 - 14 indicate mild hopelessness and 15-20 indicate severe hopelessness. Beck Hopelessness Scale was adapted into Turkish by Seber ${ }^{32}$ and Durak $^{33}$ and its calculated Cronbach's Alpha reliability coefficient was stated as 
0,85 . Item-total score correlations between points obtained from each item of the scale and scores obtained from all of the scale were found between 0,07 and 0,72 as well as 0,31 and 0,67 .

\section{Data Analysis}

Descriptive statistics were used in processing the data in the study, $t$ test was applied in paired comparison and Anova test was applied in comparing more than two groups and the results were interpreted. SPSS 10.00 program was used in evaluating the data.

\section{Findings}

Hypothesis 1. Is there a difference between Depression and Hopelessness scores of students studying in Secondary and Higher Education?

1.1. The findings on the difference between depression scores of Secondary and Higher Education students are given in table 1.

Table 1. Mean Standard deviation t Value and Significance Value of Depression Scores of Secondary and Higher Education Students

\begin{tabular}{lcccccc}
\hline & Groups & N & X & St. dv. & t & P \\
\hline DEPRESSION & Secondary & 550 & 44.07 & 8.6 & 13.9 & .000 \\
& Higher Education & 500 & 33.06 & 8.1 & & \\
\hline
\end{tabular}

Depression score averages and standard deviations of secondary school students were found as 44.07 and 8.6 respectively and depression score averages and standard deviations of higher education students were found as 33.06 and 8.1 respectively.

As a result of the significance test (t-test) of the difference between two averages, the difference was found significant. Accordingly, depression levels of secondary school students are higher than higher education students.

1.2. The findings on the difference between hopelessness scores of Secondary and Higher Education students are given in table 2. 
Table 2. Mean Standard deviation t Value and Significance Value of Hopelessness Scores of Secondary and Higher Education Students

\begin{tabular}{ccccccc}
\hline & Groups & N & X & St. dev. & t & P \\
\hline HOPELESSNESS & Secondary & 550 & 11.04 & 3.11 & 5.05 & .000 \\
& Higher Education & 500 & 8,01 & 2.36 & & \\
\hline
\end{tabular}

Hopelessness score averages and standard deviations of secondary school students were found as 11.04 and 3.11 respectively and hopelessness score averages and standard deviations of higher education students were found as 8.01 and 2.36 respectively.

The significance test (t-test) was carried out to determine if the difference between hopelessness score averages is significant or not. According to the result of the significance test (t-test) of the difference between two averages, the difference was found significant. According to the results, hopelessness levels of secondary school students are higher than higher education students.

Hypothesis 2. Is there a difference between depression and hopelessness scores of female and male students?

2.1. The findings on the difference between depression scores of female and male students are given in table 3 .

Table 3. Mean Standard Deviation t Value and Significance Level of Depression Scores of Female and Male Students

\begin{tabular}{lcccccc}
\hline & Groups & N & X & St. dev. & t & P \\
\hline DEPRESSION & Female & 450 & 48.09 & 6.03 & 8.26 & .000 \\
& Male & 600 & 31.37 & 9.01 & & \\
\hline
\end{tabular}

Depression score averages and standard deviations of female students were found as 48.09 and 6.03 respectively and depression score averages and standard deviations of male students were found as 31.37 and 9.01 respectively. As a result of the significance test (t-test) of the difference between two averages, the difference was found significant. According to the results, depression level of female students is higher than male students.

2.2. The findings on the difference between hopelessness scores of female and male students are given in table 4 .

Table 4. Mean Standard Deviation t Value and Significance Level of Hopelessness Scores of Female and Male Students 


\begin{tabular}{ccccccc}
\hline & Groups & N & X & St. dev. & t & P \\
\hline HOPELESSNESS & Female & 450 & 6.09 & 2.37 & 5.45 & .000 \\
& Male & 600 & 9.18 & 3.19 & & \\
\hline
\end{tabular}

Hopelessness score averages and standard deviations of female students were found as 6.09 and 2.37 respectively and hopelessness score averages and standard deviations of male students were found as 9.18 and 3.19 respectively. As a result of the significance test (t-test) of the difference between two averages, the difference was found significant. According to the results, male students have higher hopelessness level.

Hypothesis 3. Is there a difference between Depression and Hopelessness scores of students studying in Regular and Vocational High Schools?

3.1. The findings on the difference between depression scores of Regular and Vocational High School students are given in table 5.

Table 5. Mean Standard deviation t Value and Significance Value of Depression Scores of Regular and Vocational High School Students

\begin{tabular}{ccccccc}
\hline & Groups & $\mathbf{N}$ & $\mathbf{X}$ & St. dev. & t & P \\
\hline DEPRESSION & Regular High School & 300 & 31.10 & 6.12 & 1.54 & .546 \\
& Vocational High School & 250 & 29.23 & 4.28 & & \\
\hline
\end{tabular}

Depression score average and standard deviation of Regular High School students were found as 31.10 and 6.12 respectively and depression score average and standard deviation of Vocational High School students were found as 29.23 and 4.28 respectively.

As a result of the significance test (t-test) of the difference between two averages, the difference was not significant.

3.2. The findings on the difference between hopelessness scores of Regular and Vocational High School students are given in table 6.

Table 6. Mean Standard deviation t Value and Significance Value of Hopelessness Scores of Regular and Vocational High School Students

\begin{tabular}{ccccccc}
\hline & Groups & $\mathbf{N}$ & $\mathbf{X}$ & St. dev. & t & P \\
\hline HOPELESSNESS & Regular High School & 300 & 8.35 & 4.57 & 1.03 & .654 \\
& Vocational High School & 250 & 7.48 & 3.56 & & \\
\hline
\end{tabular}


Hopelessness score average and standard deviation of Regular High School students were found as 8.35 and 4.57 respectively and hopelessness score average and standard deviation of Vocational High School students were found as 7.48 and 3.56 respectively. As a result of the significance test (t-test) of the difference between two averages, the difference was not significant.

Hypothesis 4. Is there a difference between depression and hopelessness scores of studying in higher education programs?

4.1. Anova analysis results on depression points of students studying in different higher education programs are given in table 7 .

Table 7. Anova Analysis Results on Depression Points of Students Studying in Different Higher Education Programs

\begin{tabular}{lccc}
\hline Groups & N & X & St. deviation \\
\hline Phy. Ed. and Sports & 85 & 39.09 & 7.01 \\
Education Faculty & 60 & 35.00 & 7.05 \\
Science-Letters Faculty & 60 & 44.05 & 8.07 \\
Economics Administration Faculty & 65 & 28.13 & 6.35 \\
Engineering Faculty & 60 & 28.19 & 4.06 \\
Vocational School & 85 & 34.25 & 7.45 \\
School of Health Service & 85 & 22.01 & 3.21 \\
\hline Total & 500 & 33.07 & 6.17 \\
\hline
\end{tabular}

ANOVA

DEPRESSION

\begin{tabular}{cccccc}
\hline & Sum of Squares & df & Mean Square & F & Sig. \\
\hline Between Groups & 2427,3 & 6 & 404,56 & 6,94 &, 00 \\
Within Groups & 20272,8 & 348 & 58,26 & & \\
\hline Total & 22700,1 & 354 & & & \\
\hline
\end{tabular}

The difference in the level of 0,05 in Table 7 between depression scores of students studying in different Undergraduate Programs is significant. When the averages of the groups are analyzed, it is observed that faculties with highest depression are Science-Letters Faculty, Physical Education and Sports Vocational School, Education Faculty and Vocational School respectively.

4.2. Variance analysis results on hopelessness points of students studying in different higher education programs are given in table 8. 
Table 8. Variance Analysis Results on Hopelessness Points of Students Studying in Different Higher Education Programs

\begin{tabular}{lccc}
\hline \multicolumn{1}{c}{ Groups } & $\mathrm{N}$ & $\mathrm{X}$ & St. deviation \\
\hline Phy. Ed. and Sports & 85 & 8.20 & 3.09 \\
Education Faculty & 60 & 8.00 & 3.04 \\
Science-Letters Faculty & 60 & 10.12 & 2.05 \\
Economics Administration Faculty & 65 & 7.54 & 4.16 \\
Engineering Faculty & 60 & 6.41 & 3.08 \\
Vocational School & 85 & 9.14 & 3.58 \\
School of Health Service & 85 & 6.19 & 2.17 \\
\hline Total & 500 & 8.16 & 3.02 \\
\hline
\end{tabular}

\section{ANOVA}

\section{HOPELESSNESS}

\begin{tabular}{cccccc}
\hline & Sum of Squares & $\mathrm{df}$ & Mean Square & F & Sig. \\
\hline Between Groups & 448,1 & 6 & 74,69 & 5,49 &, 00 \\
Within Groups & 4733,2 & 348 & 13,60 & & \\
\hline Total & 5181,3 & 354 & & & \\
\hline
\end{tabular}

There is a significant difference in the level of 0,05 in Table 8 between hopelessness scores of students studying in different Undergraduate Programs. When the averages of the groups are analyzed, it is observed that faculties with highest hopelessness are Science-Letters Faculty, Vocational School, Education Faculty and Physical Education and Sports Vocational School respectively.

\section{Conclusions and Discussion}

The aim of this study is to examine depression and hopelessness levels of secondary and higher education students in terms of gender, education level, high school types and different higher education programs.

According to the result of the of the study, a significant difference was found between depression and hopelessness levels of Secondary and Higher Education students. According to the result, depression and hopelessness levels of secondary school students are higher than Higher Education students.

As it is known, secondary education which includes adolescence is a critical period regarding development and professional decisions for the future. While the 
adolescent encounters problems, such identity crisis, quick physical changes and not being able to adapt to them, leaving home, economic problems, sexual problems, thought of not being understood, criticism, conflicts between siblings, failures in courses, and problems on selection of work and profession. Also, he/she also may experience problems with family and environment and may fail to solve the crisis. All of these may cause the adolescent to experience depression. In addition, failures to enter into university, not being able to get a proper job, perceiving the future as uncertain may also cause the adolescents to experience hopelessness. When considered from the perspective of university students, they solve their identity crisis and overcome the conflicts with family and environment. The university students become effective in gaining their own independency and taking their own decisions. Also, they solve their professional uncertainty problems, and they can get better decisions regarding the future. Furthermore, developmental problems of the university students disappear. As a result, both groups experience depression and feeling of hopelessness, however, problems and uncertainty of the future for the adolescent are perceived more intensive and complicated. This situation leads them to experience depression and hopelessness and makes it harder to overcome. However, the adults may not perceive as a big problem and can easily overcome it since they are in a higher level developmentally, emotionally and cognitively. In additions, situations regarding future are clearer for them. In this case, they may not experience hopelessness as much as adolescents do.

In the studies, it was seen that there is a positive relation between depression and hopelessness ${ }^{34}$; hopelessness leads to depression and hopelessness increases the risk of suicide ${ }^{35}$; 3 ; depression prevalence in adolescents varies between $1 \%$ and $50 \%{ }^{37 ;} 38$; hopelessness levels of secondary school students are generally high; hopelessness levels of students with high depression levels are also high ${ }^{39}$; at least $50 \%$ of the adolescents coming to a health center experience depression problem ${ }^{40}$; Turkish university students are in "mild hopelessness" range ${ }^{29}$. Research results support the obtained result.

The difference between levels of depression and hopelessness for future of regular and vocational high school students is not significant. Depression and hopelessness levels of these two groups are generally in normal levels. The reason why the difference is insignificant can be told because both groups are in the same age level and they encounter similar problems.

The difference between depression and hopelessness levels of female and male students was found to be significant as $\mathrm{P}>0.05$. According to this result, depression level is high in girls and hopelessness level is high in boys. In the study, depression 
levels of the females were found to be higher than the males. The reason for this is that females face developmental problems earlier and more intensively, and they perceive the problems regarding physical development negatively since they give more importance to physical development. Also, females are subject to more pressure and control when compared to the males, and the difficulties females experience in making their own decisions and choices cause them to experience more depression. In the study, the hopelessness levels of males for the future were found to be higher than that of the females. It can be said that this situation is a result of the duties attributed to the male role by the society. In traditional child education, the males are generally trained regarding maintaining a family and earning income. In this sense, profession and income become more significant for males than females. However, economic difficulties, unemployment problems, difficulties regarding entering into university, perceiving the future as uncertain may cause the males experience more hopelessness. In the study, it was seen that boys have more hopelessness than the girls ${ }^{41 ; 42} ; 50 \%$ of males and $25 \%$ of females who apply to the clinic experience hopelessness problem ${ }^{43}$; while the rate of frequency of heavy depression is $9.6 \%$ in female students, this rate is $5.4 \%$ in male students $^{44}$; depression prevalence is more intense in girls ${ }^{16 ;} 45 ; 46$; girls experience depression more because of failing in school. Research results support obtained results.

The difference between levels of depression and hopelessness for future of students studying in different Higher Education Programs is significant. When the averages of the groups are analyzed, it was found that the faculties with the highest depression are respectively Science and Letters Faculty, Physical Education and Sports Vocational School, Education Faculty and Vocational School and the faculties with the highest hopelessness are respectively: Science and Letters Faculty, Vocational School, Education Faculty and Physical Education and Sports Vocational School. The target behaviors of the parts aimed to gain and the difficulty levels of the programs are different. If the individual cannot relate himself/herself with the education he/she gets and if he/she has to complete his/her department to get rid of the pressures although he/she is not interested in the department, he/she may experience intensive depression, because entering into university or changing the department has recently become harder. In addition, the levels to be able to find a job are quite different. The students in the departments which ensure the possibility to find a job with more ease feel safe while the students of the departments with limited job possibilities may not feel that safe and they may perceive future as uncertain and experience hopelessness. 


\section{References and Notes}

1.Öztürk, Orhan (1986). Mental Health and Disorders. İstanbul: Evrim Yayın ve Dağıtım.

2. Adasal, Rasim (1994). Medical Psychology. Ankara: Güzel İstanbul Matbaası.

3.Cüceloğlu, Doğan. (1993). Human Behavior. İstanbul: Remzi Yayınevi.

4.Köknel, Özcan. (1989). Hopelessness: Mental Collusion. İstanbul: Altın kitaplar Yayın evi.

5.Kazdin, A. E. (1988). The diagnosis of childhood disorders: assessment issues and strategies. Behavioral Assessment, 10, 67-94.

6. Costello, E. J., Edelbrock, C., Burns, B. J., Dulcan, M. K., Brent, D., \& Janiszewski, S. (1988). Psychiatric disorders in pediatric primary care. Archives of General Psychiatry, 45, 1107-1116

7. Kovacs, M., Goldston, D., \& Gatsonis, C. (1993). Suicidal behaviors and childhoodonset depressive disorders: a longitudinal investigation. Journal of the American Academy of Child and Adolescent Psychiatry, 32,8-20.

8. Kovacs, M. (1997). Depressive disorders in childhood: an impressionistic landscape. Journal of Child Psychology and Psychiatry and Allied Disciplines, 38, 287-298.

9. Puig-Antich, J., Lukens, E., Davies, M., Goetz, D., Brennan-Quattrock, J., \& Todak, G. (1985). Psychosocial functioning in pre pubertal major depressive disorders: I. interpersonal relationships during the depressive episode. Archives of General Psychiatry, 42,500-507.

10. Fleming, J. E., Offord, D. R., \& Boyle, M. H. (1989). The Ontario Child Health Study: prevalence of Childhood and adolescent depression in the community. British Journal of Psychiatry, 155,647-654.

11. Fleming, J. E., \& Offord, D. R. (1990). Epidemiology of childhood depressive disorders: a critical review. Journal of the American Academy of Child and Adolescent Psychiatry, 29, 571-580.

12. Rao, U., Weissman, M. M., Martin, J. A., \& Hammond, R. W. (1993). Childhood depression and risk of suicide: a preliminary report of a longitudinal study. Journal of the American Academy of Child and Adolescent Psychiatry, 32, 21-27.

13.Ivanenko, A., Crabtree, V.,L., Gozal, D (2005). Sleep and depression in children and adolescents. Sleep Medicine Reviews, 9,115-129.

14.Calamaro, C., J., \& Waite, R. (2009). Depression and Obesity in Adolescents. The Journal for Nurse Practitioners - JNP, 255-261.

15. Yeşilyaprak, Binnur (1986). Psychological Problems of University Youth. Psikoloji Dergisi, 5. 20.

16. Toros, Fevziye, Bilgin N. G., Buğdaycı, R., Şaşmaz ,T., Kurt, O. \& Çamdeviren, H. (2004). Prevalence of depression as measured by the CBDI in a predominantly adolescent school population in Turkey. European Psychiatry, 19, 264-271.

17. McCarty, C.A., Mason, W. A.,S., Kosterman, R., Hawkins,J., D., Lengua, L., J., \& McCauley, E. (2008). Adolescent School Failure Predicts Later Depression Among Girls. Journal of Adolescent Health, 43,180-187.

18. Kashani, J., Stoyls, M. S., Dandoy, A., Viadya, A., \& Reid, J. (1991). Correlates of Hopelessness in Psychiatrically Hospitalized Children. Comprehensive Psychiatry, 300-337.

19. Lavender, A., ve Watkins, E. (2004). Rumination and Future Thinking in Depression. British Journal of Clinical Psychology, 129-142. 
20. Bayram, G., Okay, T., Dilbaz, N., \& Açıkgöz, Ç. (2002). Anxiety, Hopelessness and Learned Powerfulness Levels and Posttraumatic Stress Disorder Frequency in Civil Defense Association Workers, Kriz Dergisi, 1-9.

21. O'Connor, R., O'Connor, D., O'Connor, S., Swalwood, J., ve Miles, J. (2004). Hopelessness, Stress and Perceptionism: The Moderating Effects of Future Thinking. Cognition and Emotion, 1099-1120.

22. Hadley, S., A. ve MacLeod, A., K. (2010). Conditional goal-setting, personal goals and hopelessness about the future. Cognition and Emotion, 24 (7), 1191-1198

23. Göleç, Cengiz (1993). Psikoterapiler. Ankara: Medikomat Basım ve Yayın.

24. Mac Leod, A., Rose, G., ve Williams , J. (1993). Components of hopelessness about the future parasuicide. Cognitive Therapy and Research, 441-445.

25. Beck, A., Kovacs, M., ve Weismann, A. (1979). Assessment of suicidal intention: The Scale for Suicide Ideation. Journal of Consulting and Clinical Psychology, 343-352.

26. Kırımoğlu, Hüseyin (2010). Examination of hopelessness levels of last grade students of Physical Education and Sports Vocational Schools in Turkey regarding employment problem. Kastamonu University Kastamonu Education Faculty,18(1), 37-46.

27. Ceyhan, A., A.(2004). Examination of Hopelessness Levels of Preservice Teachers Studying in Secondary School Branch Teaching Non-Thesis Master's Degree Program. Anadolu University Sosyal Bilimler Dergisi,4(1), 91-101.

28. Gencay, Selçuk ( 2009). Examination of Hopelessness and Life Satisfaction of Preservice Physical Education Teachers In Terms of some Variables. Elektronik Sosyal Bilimler Dergisi,8 (27), 380-388.

29.Üngören, E., \& Ehtiyar, R. (2009). Comparison of Hopelessness Levels of Turkish and German Students and Determining the Factors Affecting their Hopelessness Levels: A study on students studying Tourism. Journal of Yasar University, 4,(14),2093-2127.

30. Hisli, N. (1989). Validity and Reliability of Beck Hopelessness Scale for University Students. Psikoloji Dergisi, 7, 23.

31. Beck, A.T., Steer, R. A. (1988). Beck Hopelessness Scale Manual. San Antonio, TX: Psychological Corporation.

32. Seber, G., Dilbaz, N., Kaptanoğlu, C., Tekin, D. (1993). Hopelessness scale: Its Validity and Reliability. Kriz Dergisi, 1(3), 39-142.

33. Durak, A., Palabıyıkoğlu, R. (1994). Validity Study of Beck Hopelessness Scale. Kriz Dergisi, 2,(2), 311-319.

34. Landis, Dana et al (2007). Urban adolescent stress and hopelessness. Journal of Adolescence, 30, 1051-1070.

35. Joiner, Thomas, E. Et al (2001). Hopelessness depression as a distinct dimension of depressive symptoms among clinical and non-clinical samples. Behaviour Research and Therapy, 39, 523-536

36. Chochinov, Harvey Max et al (1998). Depression, Hopelessness, and Suicidal Ideation in the Terminally III. Psychosomatics, 39, 366-370.

37. Ay, P. \& Save, D. (2004). Adolescent Depression: Progress And Future Challenges In Prevention-Control Activities. Marmara Medical Journa, 17,(1),47-52.

38. Türkleş, S., Hacıhasanoğlu, R. \& Çapar, S. (2008). Depression among, High School Students and The Factors which Affect It. Atatürk Üniversitesi Hemşirelik Yüksekokulu Dergisi, 11,(2), 18-28. 
39. Özmen, D., Dündar, P. E., Çetinkaya, A.Ç., Taşkın, O. \& Özmen, E. (2008). Hopelessness in high school students and factors affecting hopelessness level. Anadolu Psikiyatri Dergisi, 9, 8-15.

40. Fallucco, Elise M. (2012). Use of a Standardized Patient Paradigm to Enhance Proficiency in Risk Assessment for Adolescent Depression and Suicide. Journal of Adolescent Health,1-7.

41. Çelikel, F.C. \& Erkorkmaz, Ü. (2008). Factors Related to Depressive Symptoms and Hopelessness Among University Students. Archives of Neuropsychiatry,45, 12-29.

42. Pharrıs, M. D., Resnick, D., Blum, R. W. (1997). Protecting Against Hopelessness and Suicidality in Sexually Abused American Indian Adolescents. Journal of adolescent health, 21,400-406.

43. Bolland, J. M. (2003). Hopelessness and risk behaviour among adolescents living in high-poverty inner-city neighbourhoods. Journal of Adolescence Journal of Adolescence, 26, 145-158.

44. Ertem, Ü. \& Yazıc1, S. (2006). Psycho-Social Problems and Depression in Adolescence. Aile ve Toplum Kültür Dergisi, 3, (9), 7-13.

45. Öztop, D. Behice et al (2011). The prevalence of depression and behavioral problems in the high school students. Anatolian Journal of Psychiatry, 12,204-211.

46. Eskin, M., Ertekin, K., Harlak, H., Dereboy, Ç. (2008). Prevalence of and Factors Related to Depression in High School Students. Türk Psikiyatri Dergisi, 19,(4), 382389

47. McCarty et al (2008). Adolescent School Failure Predicts Later Depression Among Girls. Journal of Adolescent Health 43,180-187.

\title{
Summary
}

\section{Depression and Hopelessness in Secondary and Higher Education Students}

\author{
Ali Haydar ŞAR \\ Sakarya University, Turkey
}

Depression and hopelessness are emotional problems which should be taken into consideration for secondary and higher education students in terms of development and education. In the research, it was tried to determine if depression and hopelessness vary according to education grades, gender and different departments. Beck Depression Scale and Beck Hopelessness Scale were applied to 1050 students in order to collect data in the research. According to obtained results, it was concluded that secondary level students have higher depression and hopelessness scale than higher education students; girls have higher depression levels than boys and boys have higher hopelessness levels than girls; depression and hopelessness levels of regular and vocational high school students do not differ; depression and hopelessness levels of higher education students differ according to genders.

Key words: Depression, hopelessness, High School, University 